\title{
蓚酸カルシウム結晶に対するオステオポンチンの構造的特徵
}

\author{
近畿大学医学部泌尿器科学教室（主任：栗田 孝教授） \\ 梅川徹

\section{STRUCTURAL CHARACTERISTICS OF OSTEOPONTIN FOR CALCIUM OXALATE CRYSTAL}

\author{
Tohru Umekawa \\ Department of Urology, Kinki University School of Medicine \\ (Director : Prof. Takashi Kurita)
}

(Background) I investigated which structural segment of osteopontin (OPN), a matrix component of urinary stones, is significantly related to the formation of urinary stones.

(Methods) I prepared several kinds of OPNs under various conditions and compared the effects of these OPNs on calcium oxalate $(\mathrm{CaOx})$ crystal using RI counts obtained by the seed crystal method and diluted urine method. Furthermore, I performed scanning electron microscopic (SEM) observation of $\mathrm{CaOx}$ crystals used in these experiments and evaluated the effects of OPN based on morphological changes in $\mathrm{CaOx}$ crystals. The following OPNs were used in this study : human recombinant OPN ( $\mathrm{rOPN}$ ), human native OPN (nOPN) purified from human milk, denatured OPN (dOPN) obtained by adding organic solvent during the course of nOPN purification, and asiaro OPN (aOPN) obtained by removing sialic acid after enzymatic digestion of nOPN.

(Results) When the effects of OPNs $(15 \mu \mathrm{g} / \mathrm{ml})$ were evaluated by the seed crystal method, the following inhibitory activities were observed : nOPN (82\%), aOPN (56\%), dOPN (49\%) and rOPN $(15 \%)$. When the effects of OPNs $(150 \mu \mathrm{g} / \mathrm{ml})$ were evaluated by the undiluted urine method, the following inhibitory activities were observed : nOPN (38\%), aOPN (27\%), dOPN (21\%) and rOPN $(0 \%)$. Furthermore, using nOPN, I performed SEM observation of $\mathrm{CaOx}$ crystals and found that nOPN mainly inhibited $\mathrm{CaOx}$ crystal aggregation.

(Conclusion) Since the inhibitory activity of nOPN was observed not only in the seed crystal method, but also in the undiluted urine method, it was suggested that nOPN may play an important role in the living body during the course of urinary stone formation. Moreover, the inhibitory activity of OPN was not due to its primary structure, but it was closely related to its higher-order structure and side chains including sialic acid. Furthermore, it was clarified that the inhibitory activity of OPN mainly resulted from inhibition of $\mathrm{CaOx}$ crystal aggregation rather than growth inhibition in these crystals.

Key words : osteopontin, seed crystal method, undiluted urine method

要旨：(背景と目的) 尿路結石のマトリックス成分の一つであるオステオポンチン $(\mathrm{OPN})$ の構造上のど の部分が結石形成に深く関与するのかを検討した。

(材料と方法) RI カウントを用いたシードクリスタル法と全尿法で, 蓚酸カルシウム結晶に与える影響 を種々の条件で作成した OPN で比較検討した. またこれらの結晶を走査電子顕微鏡で観察し, その作用 機序を結晶の形態的変化から検討した．材料には，ヒトの recombinant OPN (rOPN)，ヒト母乳から精 製した native OPN（nOPN）, denatured OPN（dOPN）と asiaro OPN（aOPN）である.

(結果) シードクリスタル法の結晶は，蛋白濃度が $15 \mu \mathrm{g} / \mathrm{ml}$ で抑制活性は，nOPN (82\%)，aOPN (56 
\%), dOPN (49\%), rOPN (15\%)であった. 全尿法では, $150 \mu \mathrm{g} / \mathrm{ml}$ の OPN 濃度で抑制活性は, nOPN $(38 \%), \mathrm{aOPN}(21 \%), \mathrm{dOPN}(21 \%), \mathrm{rOPN}(0 \%)$ 。さらにこの時の nOPN について, 結晶を電子顕 微鏡で観察したところ，nOPN は蓚酸カルシウム結晶の凝集を主に抑制している事が判明した.

(結論) nOPN はシードクリスタル法のみならず全尿法でも抑制活性を有していたことにより，生体内 でも結石形成に対して重要な役割をはたしている可能性が示唆されたままたの抑制活性は蛋白の一次 構造によるものではなく, OPN の高次構造や側鎖のシアル酸が深く関与していると考えられた.さらに この抑制活性は, 電顕の結果から主に結晶の凝集の阻害によるものである可能性が示唆された. キーワード：オステオポンチン，シードクリスタル法，全尿法

\section{緒 言}

骨をはじめとする硬組織石灰化のメカニズムに関し ては, 一人の研究者ごとに一つの石灰化の仮説がある と言われているのと同様に，尿路結石の発生原因やそ のメカニズムについても，近年多くの新しい知見がも たらされたが，判然としない部分もなお多い．結石が 形成される過程において重要な蛋白質であるマトリッ クスには, nephrocalcin ${ }^{1)}$, osteopontin $(\mathrm{OPN})^{2)}$, cal$\operatorname{protectin}^{3)}, \alpha_{1}$ antitrypsin $^{4)}$, uronic acid rich protein $^{5)}$, human prothrombin activation peptide $\mathrm{F} 1^{6)}$, $\alpha_{2}$ HS-Glycoprotein $^{7)}$, inter $\alpha$ trypsin hibitor ${ }^{8}$ などが あげられる.これらの多くは, in vitro で蓚酸カルシウ ム $(\mathrm{CaOx})$ 結晶の成長や凝縮を抑制する可能性のある 尿中物質, つまり crystal matrix protein ${ }^{6}{ }^{\text {P h human }}$ urinary crystal surface binding substance ${ }^{7)}$ して発見 されたが, OPN は分子生物学的手法を用い尿路結石中

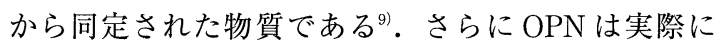
結石患者から摘出した結石からも抽出・同定され た ${ }^{10}$.

OPN は，1986 年に Oldberg ら ${ }^{111}$ がラットの培養骨 肉腫細胞からその cDNA を分離したもので, 生体内の 生理的な石灰部位（骨，歯石，内耳の耳石等）や，病 的な石灰部位 (癌細胞の石灰化, 腎結石, 動脈硬化 ${ }^{12)}$ 等) での重要な役割が明らかにされつつある，さらに癌細 胞の転移をはじめとする細胞接着因子としての役割に 関する研究もある ${ }^{10)}$.

OPN がどのような意義を持って結石内にとりこま れたか，結石形成においてどのような役割を担ってい るのかは，不明な点が多い ${ }^{14)}$ 。この解答の一部を得る には，基礎的な実験として純化した OPN が $\mathrm{CaOx}$ 結 晶の成長や凝集にどのような影響があるのか，またい かなる OPN の構造的特徵がそれに寄与しているかを 調べる基礎的な実験が必要である。今回の検討では抽 出法の違いにより三次元構造を保たせた native OPN (nOPN) と有機溶媒を用いた抽出によりその高次構造
を変性させた denatured OPN (dOPN), さらには nOPN に対して酵素的に側鎖のシアル酸を除去した asiaro OPN (aOPN)，側鎖を全く有さずまた高次構造 も異なり蛋白の一次構造のみが同じという意味で recombinant OPN (rOPN) を用いて, $\mathrm{CaOx}$ 結晶の成長 に与える影響の違いをシードクリスタル法 ${ }^{15)}$ と全尿 法 ${ }^{16)}$ で検討すると同時に, 走査型電顕 (scanning electron microscopy：SEM）でもそれらを形態的に観察し た.

\section{対象と方法}

1. Recombinant OPN 作成

腎細胞癌のため腎摘除術を施行した症例の正常部分 の腎組織から ISOGEN-LS（ニッポンジーン）で total RNA を摘出した. 今回の OPN の reverse transcription polymerase chain reaction (RT-PCR) には, OPN に対する特異的な primer (outer upstream primer (77-94) : 5'-CAGTGATTTGCTTTTGCC-3', outer downstream primer $(1206-1223): 5^{\prime}-\mathrm{GAC}$ ATAACCCTGAAGCTT-3', inner upstream primer (116-133) : 5'-ATGGATCCATACCAGTTAAACAGGCT-3' , inner downstream primer (992-1009) : 5'-GGAAGCTTTTAATTGACCYCAGAAGA-3') を 用い，全長の OPN cDNA ${ }^{11}$ を得るため nested PCR を 行った（inner upstream primerのアンダーラインは BamHI, inner down stream primer では HindIII のサ イトを示している). Total RNA $1 \mu \mathrm{g}$ を用いて逆転写 反応を RNA LA PCR Kit (TaKaRa) で行った.この反 応液（全量 $20 \mu \mathrm{l}$ ）の組成, $5 \mathrm{mM} . \mathrm{MgCl}_{2}, 1$ X. RNA PCR buffer, $1 \mathrm{mM}$. dNTP Mixture, $1 \mathrm{U} / \mu \mathrm{l}$. RNase Inhibitor, $0.25 \mathrm{U} / \mu$ l. Reverse Transcriptase, $1 \mu \mathrm{M}$. outer downstream primer, $2.5 \mu$ l. RNase Free $\mathrm{dH}_{2} \mathrm{O}$ である. これを $42.0^{\circ} \mathrm{C}$ で 60 分間, $99.0^{\circ} \mathrm{C}$ で 5 分間反応させた (GeneAmp PCR System, PERKIN ELMER)。逆転写 反応後の反応液 $20 \mu \mathrm{l}$ に試薬を添加し, 計 $100 \mu \mathrm{l}(2.5$ $\mathrm{mM} . \mathrm{MgCl}_{2}$, 1X. LA PCR buffer, $2.5 \mathrm{U} / 100 \mu \mathrm{l}$. 
TaKaRa LA Taq, $63.5 \mu$ l. RNase Free $\mathrm{dH}_{2} \mathrm{O}, 1 \mu \mathrm{M}$. outer upstream primer）とし第 1 回目の PCR 反応は $94^{\circ} \mathrm{C}$ で 2 分間, $94^{\circ} \mathrm{C}$ で 30 秒, $60^{\circ} \mathrm{C}$ で 30 秒， $72^{\circ} \mathrm{C}$ で 90 秒とし 28 サイクル行った. 第 2 回目は, 第 1 回目の PCR 産物 $2 \mu \mathrm{l}$ に減菌蒸留水 $75.5 \mu \mathrm{l}$ と以下の試薬を加 え全量を $100 \mu \mathrm{l}(0.5 \mu \mathrm{M}$. inner down and upstream primer, 1X. EX Taq buffer, $0.2 \mathrm{mM}$. dNTP Mixture, $2.5 \mathrm{U} / 100 \mu$. Ex Taq) とし, $94^{\circ} \mathrm{C}$ で 2 分間, $94^{\circ} \mathrm{C}$ で 30 秒, $60^{\circ} \mathrm{C}$ で 30 秒, $72^{\circ} \mathrm{C}$ で 90 秒の反応を 30 サイクル 行った.この PCR 産物を $1.5 \%$ アガロースゲルに展開 し, その塩基配列が既知の OPN と一致すると確認後, pMOSBlue T-vector Kit (Amersham) にてクローニン グ,さらに (New England Biolabs)で rOPNを合成した。つまり， BamHI と HindIII のサイトを有する先の全長 OPN cDNA をプラスミド (pMAL-c 2) にリゲーションし, 大腸菌（JM 109）にトランスフォームさせ培養した.

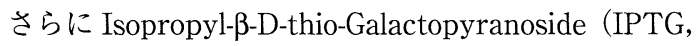
TaKaRa）にて蛋白合成を促進させ， maltose binding protein (MPB) と連続した rOPN を合成した，大腸菌 の crude cell extract から MBP-rOPN の fusion 蛋白を amyrose resin affinity column で精製し factor Xa で 切断後, Q Sepharose column で分離し rOPN の $\mathrm{N}$ 末 端アミノ酸配列の確認を行った.

2. ヒト母乳からの OPN の精製17)

七 $ト$ 母乳 $300 \mathrm{ml}$ に 対 し Diethylaminoethyl (DEAE)-Trusacryl を $50 \mathrm{~m}$ 加 え $0.1 \mathrm{nM} \mathrm{p}$-APMSF (Sigma) の存在下 $4{ }^{\circ} \mathrm{C}$ で 2 時間摚挥し, 沈殿物をろ紙 で取り， $0.2 \mathrm{M}, \mathrm{NaCl}$ を含む $0.01 \mathrm{M}$ 燐酸ナトリウム溶 液（pH 7.0） $200 \mathrm{ml}$ で洗浄，この沈殿に $0.4 \mathrm{M} \mathrm{NaCl}$ を含む $0.01 \mathrm{M}$ 燐酸ナトリウム溶液（pH 7.0） $100 \mathrm{ml}$ で粗な OPNを溶出した。これを Sodium dodecylsulfate-polyacrylamide gel electro-phoresis ( SDSPAGE, $10 \%$ gel, $0.8 \mathrm{~mm}, 100 \mathrm{~V})$ で展開し, 蛋白の $\mathrm{N}$ 端末を分析した（gas phase protein sequencer 477 A, Applied Biosystems). さらに $0.15 \mathrm{M}$ 燐酸ナトリウ ム (pH 7.0) で透析し，これに $1 / 10$ 量のクエン酸バリ ウム（塩酸バリウム：15 g, クエン酸ナトリウム：3.5 $\left.\mathrm{g} / \mathrm{H}_{2} \mathrm{O}: 100 \mathrm{ml}\right)$ を加え $\mathrm{OPN}$ を吸着させ, $0.2 \mathrm{M}$ 燐酸ナ トリウム（pH 6.8）で nOPN を溶出し蒸留水で透析し nOPNを得た。

$\mathrm{dOPN}$ は，先の粗な OPN を $0.15 \mathrm{M}$ 燐酸ナトリウム (pH 7.0) で透析し逆相高速クロマトグラフィーで抽出 した Column : CHEMOSORM 300-7L，4.6×250 mm,
Fig. 1 Seed crystal method and undiluted urine method.

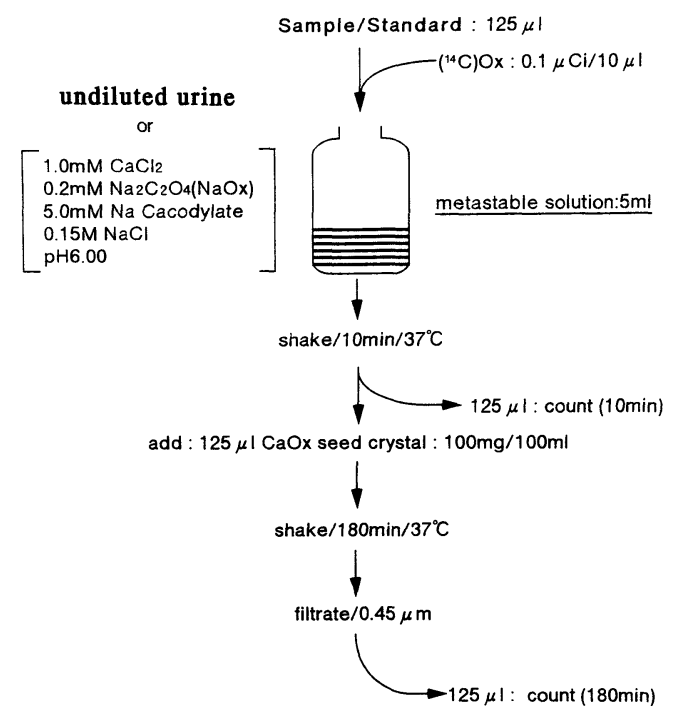

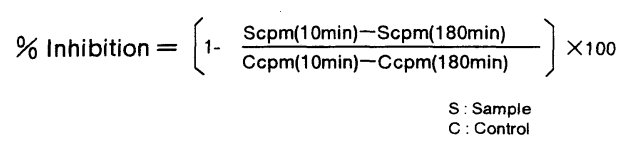

$7 \mu \mathrm{m}, 300 \mathrm{~A}$, Flow rate $: 1.0 \mathrm{ml} / \mathrm{min}$, Buffer A : 0.1 $\%$ TFA, in $\mathrm{H}_{2} \mathrm{O}$, Buffer B : $0.1 \%$ TFA, $70 \%$ acetonitrile in $\mathrm{H}_{2} \mathrm{O}$, Gradient : $0 \%$ B for 5 min, $0 \sim 70 \%$ $\mathrm{B}$ in $60 \mathrm{~min})$. 精製した $\mathrm{nOPN}$ と $\mathrm{dOPN}$ は，同様に SDS-PAGEにて純度を検討した。

$\mathrm{aOPN}$ の作成は, nOPN $10 \mathrm{mg}$ に対し 1 単位のシア リダーゼ（Seikagakukogyo）を $1 \mathrm{ml} 00.01 \mathrm{M}$ リン酸 緩衝液 $\left(\mathrm{pH} 7.3,37^{\circ} \mathrm{C}\right)$ で 24 時間反応させ, 15,000 回転 で 10 分間遠沈した上澄みを蒸留水で透析後, 凍結乾燥 し実験に用いた. 実際にこれらの nOPN と aOPN がど れくらいのシアル酸を含むかを，ランピアSIALキッ 卜（富士レビオ株式会社）で測定した。

3. シードクリスタル法と全尿法（Fig. 1)により，先 に得られた各種の OPN の抑制活性を測定した。シー ドクリスタル法には, $1.0 \mathrm{mM} . \mathrm{CaCl}_{2}, 0.2 \mathrm{mM} . \mathrm{Na}_{2} \mathrm{C}_{2} \mathrm{O}_{4}$ ( $\mathrm{NaOx}$ ), 5.0 mM. NaCacodylate, $0.15 \mathrm{M} . \mathrm{NaCl}$, pH 6.00 の人工尿を, 全尿法にはヒト尿を限外滤過フィルター (Millipore）で分子量 10.000 以上の物質を除去したultrafiltrated urine を用いた. 両方法ともに ${ }^{14} \mathrm{C}$ でラベル した Ox で放射線活性の減少を液体シンチレーション 
Fig. 2 Osteopontin (OPN) analysis by means of reverse transcription polymerase chain reaction (RTPCR). These PCR products were run individually on $1.5 \%$ agarose gel. Lane 1 is a standard marker (100 base-pair ladder, $\boldsymbol{\Delta}: 800 \mathrm{bp}$ ). Lane 2 is a band of outer primer amplification (1,129 base pair). Lane 3 is a band of inner primer amplification ( 833 base pair). Lane 4 is a blank control without cDNA.

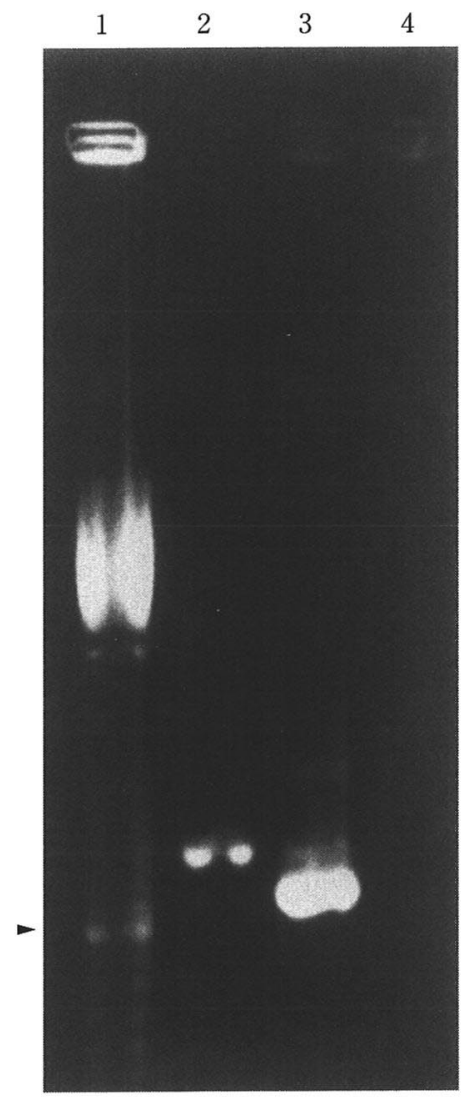

カウンター（Wallac，LKB）にて測定した。全尿法は 個々の尿の activity product ration が異なり, 違う尿を 用いる場合は supersaturation level を揃える必要があ る. 従って, シードクリスタル法同様に同じ尿で一度 に計 4 回実験を行った。シードクリスタル法では 30 $\mu \mathrm{g} / \mathrm{ml}$, 全尿法では $200 \mu \mathrm{g} / \mathrm{ml}$ の OPN 濃度で, 各種 OPN の抑制活性を一元配置分散分析法で統計学的検 定をし, 各組合わせは Fisher's Protected Least Significant Difference（PLSD）で検討した，放射能活性の減 少のみでは, $\mathrm{OPN}$ が $\mathrm{CaOx}$ 結晶の成長や凝集に対しど の程度抑制するのか判断がつかない. 従って nOPN を対象とした全尿法で, ultrafiltrated urine $20 \mathrm{ml}$ に対
Fig. 3 SDS-PAGE analysis (10\% gel, $8 \mathrm{~mm}$ thickness,Coomassie Brilliant Blue stain). Lane 1 : crude extract of E. coli (host) which induced by IPGT, lane 2 : purified fusion protein (recombinant osteopontin with maltose binding protein) eluted from amyrose column with maltose, lane 3 : recombinant osteopontin after factor $\mathrm{Xa}$ cleavage eluted from Q sepharose column.

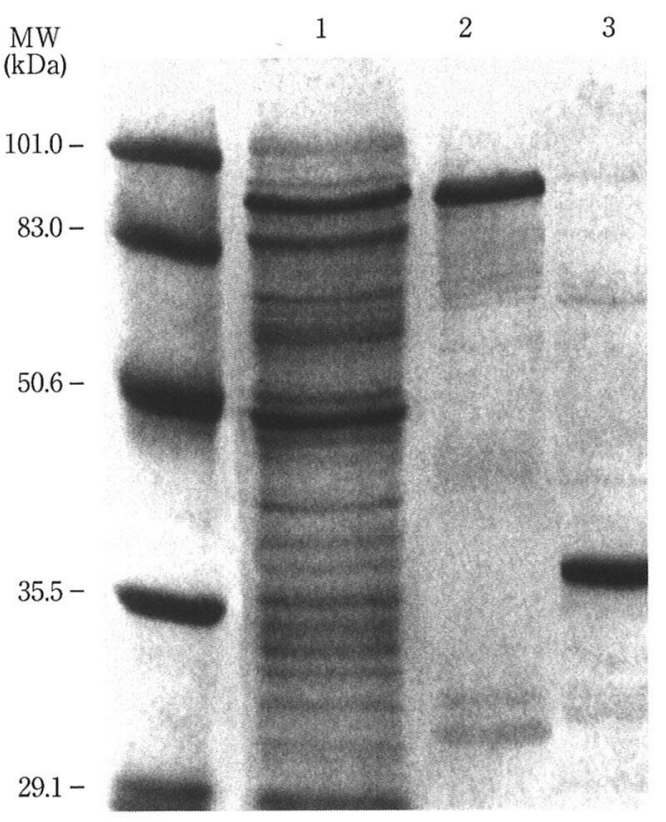

して $15 \mathrm{mM}$ 葆酸ナトリウムを $1.2 \mathrm{ml}$ 加え, $\mathrm{CaOx}$ 二水 化物結晶を作成し結晶の形態変化を SEM（JSM-840, 日本電子) で観察した。

結 果

1. rocombinant OPN の合成

RT-PCR で得られた DNA を電気泳動し(Fig. 2), そ のシークエンスの結果から OPN の全長の塩基配列と 完全に一致することを確認した，大腸菌の crude cell extract（Fig. 3, lane 1) から MBP-rOPN を amyrose resin affinity column で精製した後 (Fig. 3, lane 2), factor Xa で MBP と rOPNの結合を切断した. Q Sepharose column で MBP と rOPN の分離を行い (Fig. 4), $\mathrm{rOPN}$ の $\mathrm{N}$ 端末のアミノ酸配列が OPN と一致するこ とを確認した。この rOPN は SDS-PAGEの結果 36 kDaであった (Fig. 3, lane 3).

\section{OPN の精製}

ヒト母乳より抽出した粗な OPNを SDS-PAGEで 展開した結果である (Fig. 5)。アミノ酸配列を解析する 
Fig. 4 Q-Sepharose gel chromatography of recombinant osteopontin and maltose binding protein with $\mathrm{NaCl}$ gradient elution.

\section{Q-Sepharose}

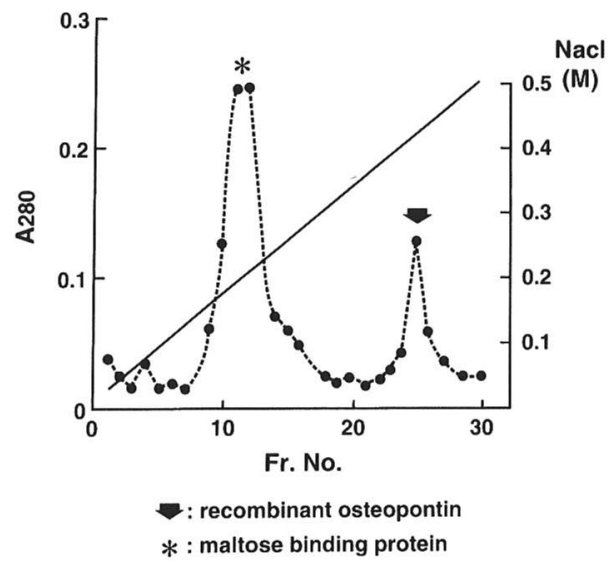

Fig. 5 Sodium dodecyl sulfate polyacrylamide gel electrophoretic band pattern of crude extracts from human milk protein ( $10 \%$ gel, $8 \mathrm{~mm}$ thickness, Coomassie Brilliant Blue stain).

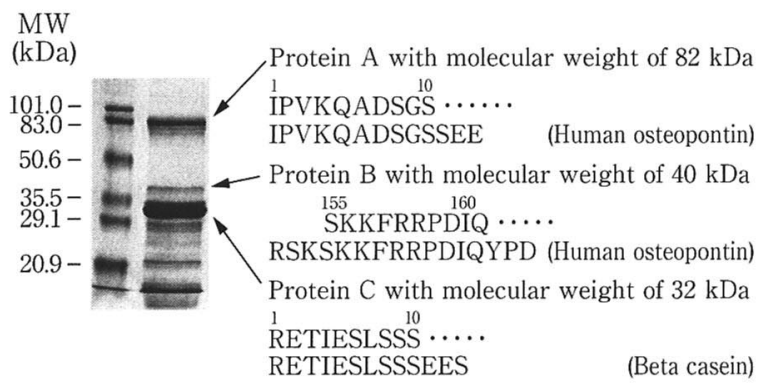

と, $82 \mathrm{kDa}$ の蛋白は OPN (全長) であった．他に 154 番目までのアミノ酸が久落した，つまり，ヘパリン結 合部位で切断された OPN（band B, $40 \mathrm{kDa}$ ）が存在し

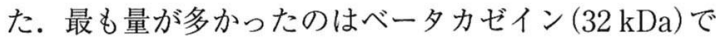
あった．また分子量の小さい蛋白質も数種類認められ た。これらをさらにバリウムで精製した nOPN とアセ トニトリルを用いた逆相カラムで精製したdOPNを 得て (Fig. 6)，同様に SDS-PAGE で展開し，その純度 を調べた (Fig. 7)。デンシトメーター (LAS-1000, 富士 フィルム) での解析の結果， $96 \%$ 以上の純度で nOPN と dOPN が得られた. 混入した残りの蛋白のほとんど は，band Bであった，aOPN 作成の結果は，nOPN
Fig. 6 Reversed-phase chromatography of denatured osteopontin (d-OPN) from human milk in silica column $\left(\mathrm{C}_{18}\right)$ with acetnitrile gradient elution. Protein rich fractions containing d-OPN $(\star)$ were pooled for further analysis.

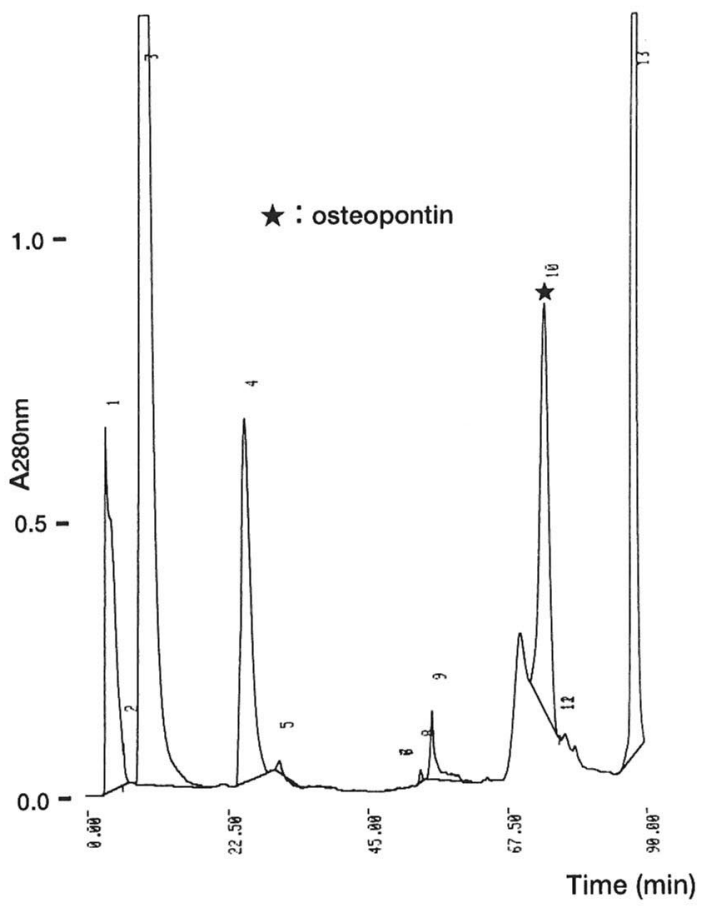

のシアル酸含有量が5\%であったものが，シアリダー ゼ消化後は $1 \%$ にった。

3. シードクリスタル法と全尿法の結果

シードクリスタル法では, 各種 OPN の濃度が $30 \mu \mathrm{g}$ $/ \mathrm{dl}$ で, $\mathrm{nOPN}: 86.1 \pm 7.3$ (\%, 平均士標準偏差), aOPN : $58.7 \pm 5.2$, dOPN $: 51.1 \pm 2.9$, rOPN $: 17.8 \pm$ 2.8 , ピロリン酸：65.1 \pm 5.6 の抑制活性であった（Fig. 8). 全尿法の結果は同様に, OPN 濃度が $200 \mu \mathrm{g} / \mathrm{dl}$ で, nOPN : 47.4 \pm 4.7 , aOPN : $32.1 \pm 2.3$, dOPN : 22.0 $\pm 2.7, \mathrm{rOPN}: 5.2 \pm 0.6$, ピロリン 酸: $86.5 \pm 3.2$ で あった (Fig. 9). 両実験系ともに一元配置分散分析を 用いた検定の結果，全体として各種の OPN 間に有為 なばらつきが認められた（p<0.01）。ささらにFishers's PLSD でそれぞれの 2 群間を比較した結果，全尿法の $\mathrm{nOPN}$ と $\mathrm{aOPN}$ の間と $\mathrm{aOPN}$ と dOPN の間には統計 学的に有為な差が認められなかったが，前者が後者よ りも值が大きい傾向があった。 それ以外の群間の組合 わせでは，全て有為な差が認められた $(\mathrm{p}<0.01)$ ．陽性 のコントロールとして用いた pyrophosphoric acid（和 
Fig. 7 SDS-PAGE pattern of purified osteopontin (OPN) from crude extracts from human milk (10 $\%$ gel, $8 \mathrm{~mm}$ thickness, Coomassie Brilliant Blue stain). Lane 1 : native OPN, lane 2 : denatured OPN.

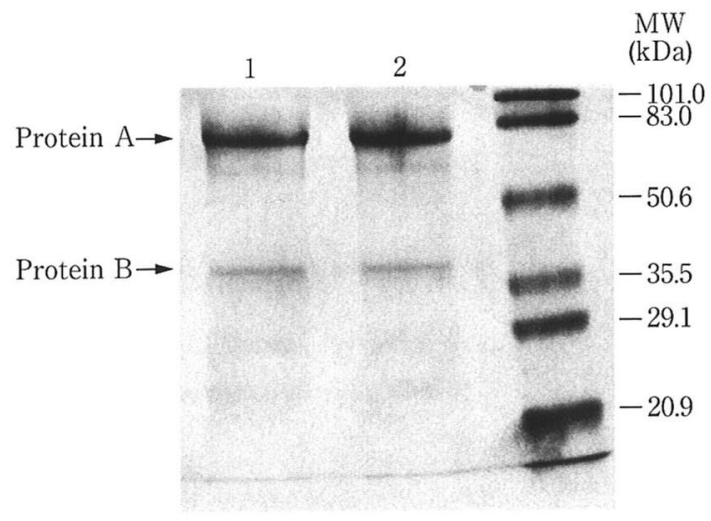

Fig. 8 Inhibitory activity in seed crystal method.

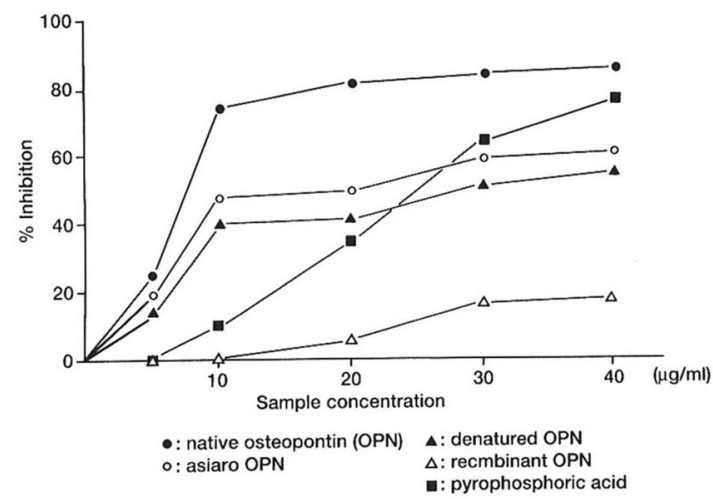

光純薬）は, 既に報告されているのと同程度の抑制活 性であった

4. SEM による $\mathrm{CaOx}$ 結晶の観察の結果（Fig. $10 \mathrm{a}$, b)

$\mathrm{nOPN}(200 \mu \mathrm{g} / \mathrm{dl})$ を対象とした全尿法で $\mathrm{CaOx}$ 結晶 を観察した結果, nOPN を添加すると凝集はほぼ完全 に停止しており結晶数も少ない傾向にあった. 結晶の 成長については明らかに阻害しているとは断定できな かった。

\section{考案}

われわれは尿路結石のマトリックス成分は腎組織成 分の一つであるとの仮説を立て, 腎組織の cDNA と尿 路結石蛋白に対するポリクローナル抗体を作成し Sanger 法で尿路結石のマトリックス成分をクローニ ングするとともに, その塩基配列とアミノ酸配列を決
Fig. 9 Inhibitory activity in undiluted urine method.

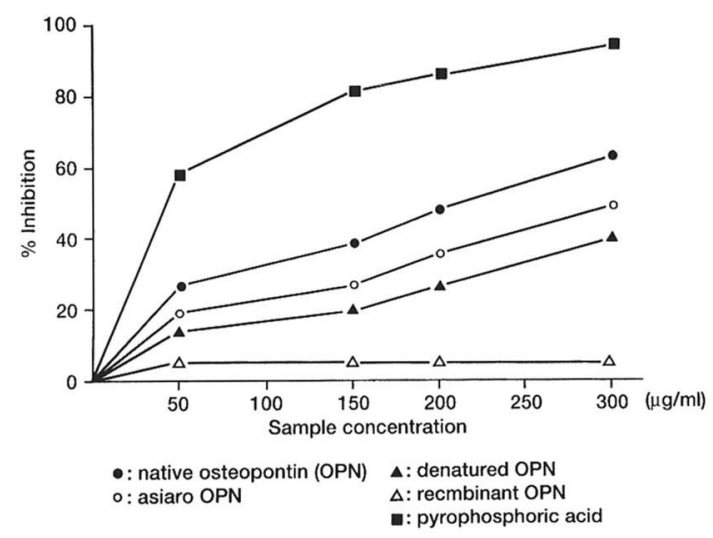

定した. その結果, これらの一つが OPN であることを 明らかにした ${ }^{18)}$ 19).ささらに尿路結石中のマトリックス から OPNを初めて分離精製した99.また実験的に作 成した結石形成ラットモデルでは，遠位尿細管上皮細 胞を中心とした OPN mRNA の発現が増加することを mouse cRNA probe による in situ hybridization 法で 確認した ${ }^{2021}$. この OPN mRNA 発現の増加は, 実験 的に誘発した腎孟腎炎や水腎症でも起こることが North blot 法で確認されており，動物実験レベルでは あるが興味が持たれる ${ }^{222}$. 2 . 犬の遠位尿細管由来の細 胞である $\mathrm{MDCK}$ 細胞は, $\mathrm{CaOx}$ 結晶と能動的な接着を 行うが，これに OPNが大きく関与することも明らか となった211.しかし実際に OPN は結石形成において promoter かあるいは inhibitor なのかといった基本的 な部分においてもなお, 明確に説明できない点が残る。

以前より OPN を始めとして尿路結石の形成に関与 すると考えられるマトリックス成分が次々と試験管レ ベルで単離されているが, これらが生体内での結石形 成においてどのような機能を果たしているのかを単純 に解橎することは困難である ${ }^{26277}$. OPN に関しては, 各種の石灰化部位と OPN mRNA 発現の強い部位とが 良く一致する一方で, OPN はハイドロキシアパタイト 結晶の成熟を逆に抑制するとの報告もある29. にOPN は周囲の状況に応じて Ca を放出したり蓄積 したりするという二面性を持つ可能性があり, 石灰化 における機能や，何かの組織が石灰化したという一部 の事実だけで OPN の役割すべてを論じることは危険 である。従って, OPN の尿路結石発生に扔ける役割を 明らかにするには, 純化した OPN の生化学的な基礎 的検討やその遺伝子発現, さらに組織化学的な検討が 
Fig. 10 Scanning electron microscopic findings of calcium oxalate dehydrate crystals at 180 minutes after addition of an overload of sodium oxalate to the undiluted urine method.

A (left side). ultrafiltrated urine (UF) as a control $(\times 1,000)$

$B$ (right side). UF + osteopontin (native, $150 \mu \mathrm{g} / \mathrm{ml}, \times 1,000$
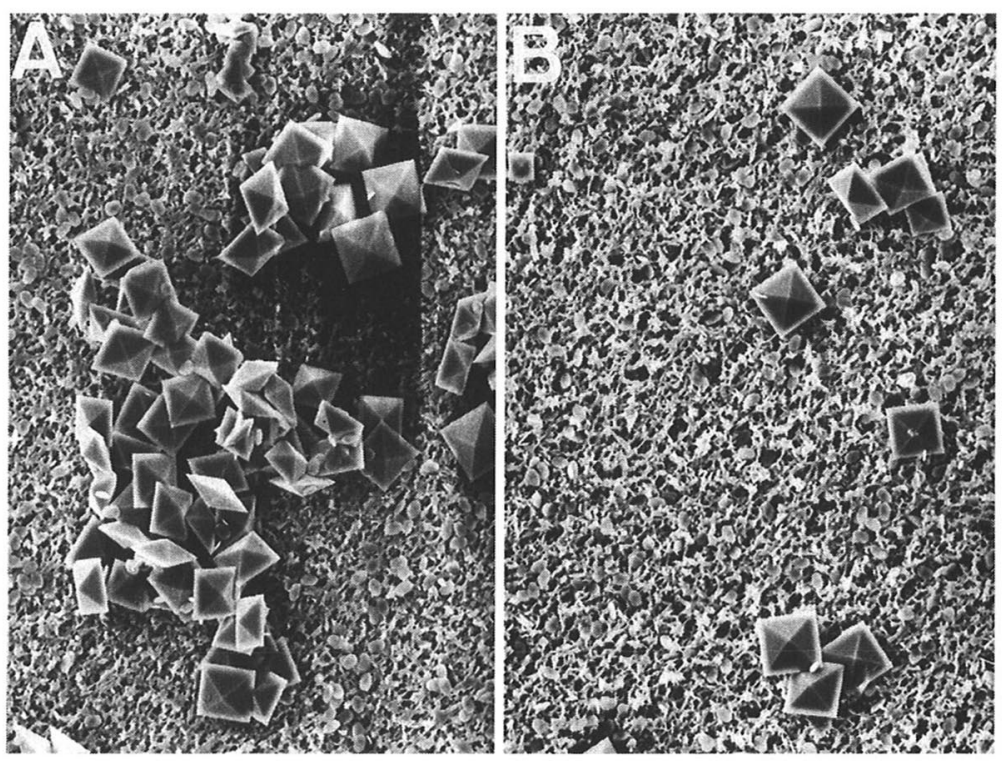

総合的になされるべきである.

OPN は約 35,000 のポリペプチドを骨格に持つ蛋白 であり,アミノ酸組成の特徴としてはカルシウムイオ ンに親和性を有するアスパラギン酸・グルタミン酸が 全体の $50 \%$ 以上と非常に多いことがあげられる.さら にセリンリン酸が 1 分子中に 12 個, スレオニンリン酸

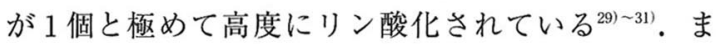
た側鎖の糖質は $16.6 \%$ （W/W），なかでもシアル酸が $4.4 \%(\mathrm{~W} / \mathrm{W})$ と多い.さらに $\mathrm{N}$ 端末にはシグナル配列 があり OPNがまさに細胞外に分泌されるタンパク質 であることを示している.

今回の検討では側鎖を全く有さない OPN という観 点から rOPN を作成した，これは側鎖のみならずその 立体構造も大きく異なり, 酸性アミノ酸を多く含むと いうnOPNのアミノ酸一次構造上の特徵のみが同じ ということである。ヒト母乳由来の OPN を今回用い たのは，尿より容易かつ大量にnOPN を回収できるた めである ${ }^{17}$. しかし OPN が分泌される組織が違った 場合，主に側鎖のリン酸化の状態などが若干変化する ことが予想される，アミノ酸の一次配列の差はほとん どないと考えられるが, 尿中の nOPN についての検討 は今後の課題と考える. OPNの側鎖のシアル酸は,
シードクリスタル法で抑制活性を有する可能性がすで に報告されている32．これを酵素で切断した 作成して検討の対象の一つとした．また OPN の精製 過程で有機溶媒を用いた逆相 HPLC で精製し, 結果と してその水素結合やイオン結合などの非共有結合を破 壞し高次構造を変化させた $\mathrm{dOPN}$ も検討材料とした. 今回の結果から, nOPN $>$ aOPN $>d O P N>r O P N$ の順に シードクリスタル法・全尿法ともに抑制活性が高かっ た.つまり，側鎖も高次構造も形成しないrOPNが最 も抑制活性が低く，次いで側鎖は有するが高次構造の みが変性した dOPN, 高次構造は保っているがシアル 酸のみが欠損した $\mathrm{aOPN}$ 酸性アミノ酸, nOPN の順に 活性を有する結果であった。酸性アミノ酸が多いとい う一次構造上の特徽を OPN は有するが, これのみで はほとんど活性はなく, 側鎖や高次構造が極めて重要 であることが示唆された。

シードクリスタル法で抑制活性がある物質は散見さ れるが(5)7110), 全尿法で抑制活性がある蛋白は prothrombin fragment F 1 などが報告されているにす ぎない( ${ }^{6)}$.シードクリスタル法は再現性もあり簡便な 方法だが, 溶液が蓚酸とカルシウムから構成されてい るために in vitroの状態とはかけ離れており，スク 
リーニング的手法であるといえる．抑制活性がシード クリスタル法で認められたとしても，全尿法で活性が なければ結石形成に関して重要な蛋白とは考えにく い. Chambers 等の報告 ${ }^{33)}$ によると OPN の尿中濃度は 通常 10 $40 \mu \mathrm{g} / \mathrm{ml}$ 程度である. ある蛋白の抑制活性 をシードクリスタル法で検討する場合，その蛋白の生 理的な尿中濃度は実験における至適濃度にはよいであ ろうが，果たして本当にそれだけでよいのだろうか。 つまり尿中結石や腎の石灰化の多くが腎臟の一部に起 こるように，何らかの機転 (詳細は原因不明であるが) により一部の尿細管上皮細胞で, OPN の産生が強く充 進する可能性がある。この時その部位の尿細管中の, いわゆる原尿中 OPN 濃度は，先の生理的な值よりも 局所で数倍高くなることが予想される．今回の実験結 果では, 全尿法にて $300 \mu \mathrm{g} / \mathrm{ml}$ の濃度で約 $60 \%$ の抑制 活性を nOPN が有していたことは，以上の理由により 結石形成に関与する重要な物質として意味があると考 えられる。

結晶の形態を SEM で検討し, OPN の $\mathrm{CaOx}$ 結晶に 与える抑制活性は結晶凝集に起因することを明らかに した。また，コールターカウンターを用いた検討が追 加して必要であると考えられる，結晶の成長について は，今回の実験系ではコントロールのものと大差はな かったために, SEM の観察からは明らかに阻害すると の結論は得られなかった。

生体内においても OPN が $\mathrm{CaOx}$ 結晶に対して今回 のような in vitro の実験と同じ働きをするとは言い切 れない．特に何らかの基質の上に OPN が結合したよ うな実験系 ${ }^{26)}$ 27)の開発により，もちろんこの方が全尿 法よりもさらに生体（尿細管や集合管内など）に近い と考えられるが, OPN の結石形成に関わるいくつかの 仮説に対して今後有益な情報がえられるものと期待さ れる。

\section{結 論}

1.ヒト母乳から native OPN を精製し,さらに denatured OPN， asiaro OPN を作成するとともに，recombinant OPNを合成した.

2.シードクリスタル法と全尿法で，各種 OPN が葆 酸カルシウム結晶の増大に与える影響を検討した. 両 方法ともに，結晶に対する抑制活性は，native OPN> asiaro OPN>denatured OPN $>$ recombinant OPN の 順 に強かった.

3. 全尿法における走査型電顕での結晶の観察結果よ り, OPN は葆酸カルシウム結晶の凝集を主に抑制する
ことが示唆された。

4. 蓚酸カルシウム結晶に対する抑制活性には, OPN の高次構造, 次いでシアル酸などの側鎖の存在が重要 であるが, 蛋白の一次構造それ自体では，ほとんど抑 制活性を有しないことが明らかとなった。

稿を終えるにあたり，御指導ならびに御校閲を賜った近 畿大学医学部泌尿器科学教室・栗田 孝教授ならびに市立 貝塚病院・井口正典先生に深謝いたします。

なお，本研究は平成 10 年度の「財団法人大阪難病研究財 団」の助成によるものである。

\section{文献}

1) Nakagawa, Y., Abram, V., Kedzy, F.J., Kiser, E.T. and Coe, F.L. : Purification and Characterization of the principal inhibitor of calcium oxalate monohydrate crystal growth in human urine. J. Bio. Chem., 258, 12594-12600, 1983.

2) Kohri, K., Suzuki,Y., Yoshida, K., Yamamoto, K., Amasaki, N., Yamate, T., Umekawa, T., Iguchi, M., Sinohara, H. and Kurita, T. : Molecular cloning and sequencing of cDNA encoding urinary stone protein, which is identical to osteopontin. Biochem. Biophys. Res. Commun., 184, 859-864, 1992.

3) Umekawa, T. and Kurita, T. : Calprotectin-like protein is related to soluble organic matrix in calcium oxalate urinary stone. Biochem. Mol. Bio. Int., 34, 309-313, 1994.

4) Umekawa, T., Kohri, K., Amasaki, N., Yamate, T., Yoshida, K., Yamamoto, K., Suzuki, Y., Sinohara, H. and Kurita, T. : Sequence of urinary protein, identical to alpha-one antitrypsin, which lacks 22 amino acids, Biochem. Biophys. Res. Commun., 193, 1049-1053, 1993.

5) Atmani, F., Lacour, B., Jungers, P., Drucke, T. and Daudon, M. : Reduced inhibitory activity of uronic-acid-rich protein in urine of stone formers. Urol. Res., 22, 257-260, 1994.

6) Suzuki, K., Moriyama, M., Nakajima, C., Kawamura, K., Miyazawa, K., Tsugawa, R., Kikuchi, N. and Nagata, K. : Isolation and partial characterization of crystal matrix protein as a potent inhibitor of calcium oxalate crystal aggregation : evidence of activation peptide of human prothrombin. Urol. Res., 22, 45一50, 1994.

7) Honda, M., Yoshioka, T., Yamaguchi, S., Yoshimura, K., Miyake, O., Utsunomiya, M., Koide, T. and Okuyama, A. : Characterization of protein components of human urinary crystal surface binding substance. Urol. Res., 22, 355-360, 1997.

8) Tang, Y., Grover, P.K., Moritz, R.L., Simpson, R.J. and Ryall, R.L. : Is nephrocalcin related to the urinary derivative (bikunin) of inter- $\alpha$-trypsin inhibitor? Br. J. Urol., 76, 425—430, 1995. 
9) Yamate, T., Umekawa, T., Iguchi, M. and Kurita, $T$. : Detection of osteopontin as matrix protein in calcium-containing urinary stones. Acta Urol. Jpn., 43, 623-627, 1997.

10）郡健二郎, 廣田誠一, 伊藤尊一郎, 梅川 徹, 栗田 孝：尿路結石の石灰化の分子機構. 細胞工学, 13 ： 1082-1089, 1994.

11) Oldberg, A., Franzen, A. and Heingard, D. : Cloning and sequence analysis of rat bone sialoprotein (osteopontin) cDNA reveals an Arg-Gly-Asp cellbinding sequence. Proc. Natl. Acad. Sci. USA, 83, $8819-8823,1986$.

12) Hirota, S., Imakita, M., Kohri, K., Ito, A., Morii, E., Adachi, S., Kim, H., Kitamura, Y., Yutani, C., and Nomura, S. : Expression of osteopontin messenger RNA by macrophages in atherosclerotic plaques. A. J. Pathol., 143, 1003-1008, 1993.

13) Chambers, A.F., Hota, C. and Prince, C.W. : Adhesion of metastatic, ras-transformed NIH 3 T 3 cells to osteopontin, fibronectin, and laminin. Cancer Research, 53, 701-706, 1993.

14）山手貴詔, 梅川 徹, 井口正典, 栗田 孝, 郡健二 郎：尿路結石症の分子生物学的診断. 臨泌, 52, 213-221, 1998.

15) Robertson, W.G. and Peacock, M. : Calcium oxalate crystalluria amd inhibitors of crystallization in recurrent renal stone-formers. Clinical Science, 43, 499-506, 1972,

16) Ryall, R.L., Hibberd, C.M. and Marshall, V.R. : A method for studying inhibitory activity in whole urine. Urol. Res., 13, 285-289, 1985.

17) Senger, D.R., Perruzzi, C.A., Paradopoulos, A. and Tenen, D.G. : Purification of a human milk protein closely similar to tumor-secreted phosphoproteins and osteopontin. Biochem. Bio. Acta., 996, 43-48, 1989.

18) Kurita, T. and Umekawa, T. : Urinary stonematrix ; osteopontin and calprotectin - Acta Med. Kinki Univ., 20, 267-278, 1995.

19) Kohri, K., Fujita, K., Itoh, T., Tawad, T., Sakakura, T., Umekawa, T. and Kurita, T. : Purification and characterization of urinary stone protein. Aktuelle Urologie, 27, 27-29, 1996.

20) Umekawa, T., Kohri, K., Kurita, T., Hirota, S., Nomura, S. and Kitamura, Y. : Expression of osteopontin messenger RNA in the rat kidney on experimental model of renal stone. Biochem. Mol. Bio. Int., 35, 223-230, 1995.

21) Umekawa, T., Yamate, T., Amasaki, N., Kohri, K. and Kurita, T. : Osteopontin mRNA in the kidney on an experimental rat model of renal stone formation without renal failure. Urol. Int., 55, 6-10, 1995.

22) Amasaki, N., Yamate, T., Umekawa, T., Ishikawa, Y., Kajikawa, H. and Kurita, T. : Regulation of the expression of OPN mRNA in the rat as an experi- mental model of renal stone disease. Int. Urol., 3 , $88-91,1996$.

23) Kohri, K., Nomura, S., Kitamura, Y., Nagata, T., Yoshioka, K., Iguchi, M., Yamate, T., Umekawa, T., Suzuki, Y., Sinohara, H. and Kurita, T. : Structure and expression of the mRNA encoding urinary stone protein (osteopontin). J.Bio. Chem., 268, 15180-15184, 1993.

24) Yamate, T., Kohri, K., Umekawa, T., Amasaki, N., Ishikawa, Y., Iguchi, M. and Kurita, T. : The effect osteopontin on the adhesion of calcium oxalate crystals to madin-darby canine kidney cells. Eur. Urol., 30, 388-393, 1996.

25）久保木芳徳, 藤沢隆一：石灰化の機序とその障害. The Bone, 5, 27-34, 1991.

26) Doi, Y., Okuda, R., Takezawa, Y., Shibata, S., Moriwaki, Y., Wakamatsu, N., Shimizu, N., Moriyama, K. and Shimokawa, H. : Osteopontin, inhibiting de novo formation of apatite in the presence of collagen. Calcif. Tissue Int., 44, 200-208, 1989.

27) Fujisawa, R., Kuboki, Y. and Sasaki, S. : Effects of dentin phosphophoryn on precipitation of calcium phosphate in gel in vitro. Calcif. Tissue Int., 41, $44-47,1987$

28) Boskey, A.L., Maresca, M., Ullrich, W., Doty, S.B., Butler, W.T. and Prince, C.W. : Osteopontinhydroxyapatite interactions in vitro : inhibition of hydroxyapatite formation and growth in a gelatin-gel. Bone Mineral, 22, 147-159, 1993.

29) Craig, A.M. and Denhardt, D.T. : The Murine gene encoding secreted phosphoprotein 1 (osteopontin) : promoter structure, activity, and induction in vivo by estrogen and progesterone. Gene, 100, 163-171, 1991.

30) Manuel, M.P., Prince, C.W., Gay, S., Austin, R.L. and Butler, W.T. : 44-kDal bone phosphoprotein (osteopontin) antigenicity at ectopic sites in newborn rats : kidney and nervous tissues. Cell Tissue Res., 251, 23-30, 1988.

31) Singh, K., Devouge, M.W. and Mukherjee, B.B. : Physiological properties and differential glycosylation of phosphorylated and nonphosphorylated forms of osteopontin secreted by normal rat kidney cells. J. Bio. Chem., 265, 18696-18701, 1990.

32）紺屋英児, 梅川 徹, 栗田 孝, 井口正典, 片岡喜 代徳：カルシウム含有上部尿路結石患者における 血清及び尿中シアル酸濃度の測定. 日泌尿会誌, 88, 917-922, 1997.

33) Bautista, D.S., Denstedt, J., Chambers, A.F. and Harris, J.F. : High frequency of electrophoretic mobility variations of osteopontin in the urine of patients with calcium oxalate kidney stones. J. Urol., 153, 491, 1995.

(1998 年 8 月 21 日受付， 12 月 17 日受理，特別揭載) 